\title{
TNF- $\alpha$ is crucial for the development of autoimmune arthritis in IL-1 receptor antagonist-deficient mice
}

\author{
Reiko Horai, ${ }^{1,2}$ Akiko Nakajima, ${ }^{1}$ Katsuyoshi Habiro, ${ }^{3}$ Motoko Kotani, ${ }^{3}$ Susumu Nakae, ${ }^{1}$ \\ Taizo Matsuki, ${ }^{1}$ Aya Nambu, ${ }^{1}$ Shinobu Saijo, ${ }^{1}$ Hayato Kotaki, ${ }^{1}$ Katsuko Sudo, ${ }^{1}$ Akihiko Okahara, ${ }^{4}$ \\ Hidetoshi Tanioka, ${ }^{4}$ Toshimi Ikuse, ${ }^{4}$ Naoto Ishii, ${ }^{5}$ Pamela L. Schwartzberg, ${ }^{2}$ \\ Ryo Abe, ${ }^{3}$ and Yoichiro Iwakura ${ }^{1}$
}

\begin{abstract}
${ }^{1}$ Center for Experimental Medicine, Institute of Medical Science, University of Tokyo, Tokyo, Japan. ${ }^{2}$ National Human Genome Research Institute, $\mathrm{NIH}$, Bethesda, Maryland, USA. ${ }^{3}$ Research Institute for Biological Sciences, Tokyo University of Science, Chiba, Japan. ${ }^{4}$ Santen Pharmaceutical Co., Osaka, Japan. ${ }^{5}$ Department of Microbiology and Immunology, Tohoku University Graduate School of Medicine, Sendai, Japan.
\end{abstract}

\begin{abstract}
IL-1 receptor antagonist-deficient (IL-1Ra-/-) mice spontaneously develop autoimmune arthritis. We demonstrate here that $T$ cells are required for the induction of arthritis; $T$ cell-deficient IL-1 $\mathrm{Ra}^{-/-}$mice did not develop arthritis, and transfer of IL-1 $\mathrm{Ra}^{-/-} \mathrm{T}$ cells induced arthritis in $n u / n u$ mice. Development of arthritis was also markedly suppressed by TNF- $\alpha$ deficiency. We found that TNF- $\alpha$ induced OX40 expression on T cells and blocking the interaction between either CD40 and its ligand or OX40 and its ligand suppressed development of arthritis. These findings suggest that IL-1 receptor antagonist deficiency in T cells disrupts homeostasis of the immune system and that TNF- $\alpha$ plays an important role in activating T cells through induction of OX40.
\end{abstract}

\section{Introduction}

RA is a systemic, chronic, inflammatory disorder exhibited most commonly in the joints. Although various factors including genetic factors, environmental factors, and infectious agents have been suggested as causes of the disease (1), so far the etiology and pathogenesis have not been completely elucidated. Patients often produce autoantibodies against various self components such as IgGs, type II collagen, and nuclear antigens, suggesting an autoimmune nature of the disease (2). Many proinflammatory cytokines, including IL- 1 and TNF- $\alpha$, chemokines, and growth factors, are expressed in diseased joints, forming a complex cytokine network. It is widely believed that dysregulation of the cytokine network contributes to the pathogenesis of RA (3).

IL-1 is a prototype proinflammatory cytokine and is produced by various types of cells, including monocytes/macrophages, lymphocytes, and synovial lining cells (4). Since IL-1 induces inflammation, promotes synovial cell growth, and promotes differentiation of osteoclasts, an important role for this cytokine in the development of RA has been suggested $(1,5)$. IL-1 receptor antagonist (IL-1Ra) is an endogenous inhibitor of IL-1. IL-1Ra production is induced by a number of other cytokines, viral products, and acute-phase proteins and is augmented in patients with autoimmune and inflammatory diseases, suggesting that IL-1Ra may play regulatory roles in these diseases (6). TNF- $\alpha$ is also thought to be importantly involved in the inflammation and bone destruction in RA. TNF- $\alpha$ is produced mainly by monocytes/macrophages, which are activated by soluble components of bacteria and by direct contact with activated $\mathrm{T}$ cells at inflammatory sites. The production

Nonstandard abbreviations used: CD40L, CD40 ligand; CIA, collagen-induced arthritis; IL-1Ra, IL-1 receptor antagonist; PEC, peritoneal exudate cells; $\mathrm{RF}$, rheumatoid factor.

Conflict of interest: The authors have declared that no conflict of interest exists.

Citation for this article: J. Clin. Invest. 114:1603-1611 (2004).

doi:10.1172/JCI200420742. of IL- 1 is coordinated with that of TNF- $\alpha$, and they mutually stimulate each other's production. Overproduction of these cytokines by gene manipulation has been found to predispose the organism to inflammatory arthritis (7-10).

Cumulative evidence suggests that $\mathrm{T}$ cell-mediated autoimmune responses play a crucial role in the pathogenesis of RA. In fact, it has been demonstrated that $T$ cells from RA patients can cause inflammatory arthritis in SCID mice (11). T cells that invade tissues and cause autoimmune destruction express activation antigens that are not expressed on normal resting $T$ cells. These activation antigens include the IL-2 receptor $\alpha$ (CD25), CD69, CD44, CD40 ligand (CD40L; also known as CD154), and OX40 (also known as CD134) (12) CD40L on T cells and its receptor on APCs, as well as OX40 on T cells and its ligand (OX40L) on APCs, generate costimulatory signals that enhance $\mathrm{T}$ cell proliferation and cytokine production. Indeed, the expression of OX40 on T cells in rheumatoid synovial tissues is quite pronounced in some patients (12), and blocking either CD40L or OX40L in vivo reduces the severity of collagen-induced arthritis (CIA), experimental allergic encephalomyelitis, and inflammatory bowel disease in animal models of these diseases $(13,14)$. However, the molecular mechanisms for the induction of these costimulatory molecules in RA are not fully understood. We previously reported that IL-1 plays an important role in enhancing T cell-APC interactions through induction of CD40L and OX40 on T cells (15). Thus, excess IL-1 signaling may activate these pathways, leading to the development of $\mathrm{T}$ cell-mediated autoimmune diseases.

We previously reported that IL-1 $\mathrm{Ra}^{-/-}$mice on the BALB/c background spontaneously develop chronic inflammatory arthropathy (9). Histopathology showed marked synovial and periarticular inflammation, with articular erosion caused by invasion of granulation tissues closely resembling that of RA in humans. Moreover, elevated levels of antibodies against immunoglobulins (rheumatoid factor [RF]), type II collagen, and double-stranded DNA were detected in sera of these mice, consistent with the development 


\section{Table 1}

Incidence of arthritis in IL-1 $\mathrm{Ra}^{-/-}$scid/scid mice

$\begin{array}{lc}\text { Genotype of scid loci } & \text { Incidence (\%) } \\ \text { scid/scid } & 0 / 6(0 \%)^{A} \\ \text { scid/+ } & 9 / 11(82 \%) \\ +/+ & 7 / 8(88 \%)\end{array}$

Incidence of arthritis was judged at 20 weeks of age. Development of arthritis was completely suppressed in T cell-deficient IL-1Ra-'scid/scid mice. ${ }^{A} P<0.01$ by chi-square for independence test.

of autoimmunity. Proinflammatory cytokines such as IL-1 $\beta$, IL-6, and TNF- $\alpha$ were overexpressed in the joints, indicating regulatory roles of IL-1Ra in the cytokine network. These data therefore suggested that IL-1Ra is crucial for the homeostasis of the immune system. It is not known, however, which cells in the immune system are crucial for the regulation of IL-1 and its actions, or furthermore, which cytokines are involved in the pathogenesis of arthritis in this model.

In this study, to elucidate the pathogenesis of the autoimmune arthritis in IL-1 $\mathrm{Ra}^{-/}$mice, we assessed the role of T cells in the development of arthritis by transferring $\mathrm{T}$ cells from IL-1 $\mathrm{Ra}^{-/-}$mice to $n u / n u$ mice and by intercrossing IL-1 Ra- ${ }^{-/}$mice with $\mathrm{T}$ cell-deficient mice. We show that IL-1 Ra-/- deficiency in T cells is enough for the development of arthritis. Furthermore, we analyzed the role of TNF- $\alpha$ in this model by producing TNF- $\alpha^{-/-} \mathrm{IL}-1 \mathrm{Ra}^{-/-}$mice, and we were able to demonstrate that TNF- $\alpha$ is crucial for the development of arthritis, as it induces OX40 on T cells. Treatment with anti-CD40L or anti-OX40L Ab suppressed disease, demonstrating the importance of CD40-CD40L and OX40-OX40L interactions for the development of autoimmune arthritis.

\section{Results}

Development of arthritis is suppressed in $T$ cell- and B cell-deficient $I L-1 \mathrm{Ra}^{-/-}$mice. IL-1 Ra'-/- mice on the BALB/c background spontaneously developed chronic inflammatory arthritis. Since high levels of RF, antibody to type II collagen, and antibody to doublestranded DNA are observed in IL-1 $\mathrm{Ra}^{-/-}$mice, we hypothesized that there could be an autoimmune mechanism for the pathogenesis. To address this question, we evaluated the contribution of $\mathrm{T}$ cells and/or B cells to the development of arthritis in IL-1Ra-/- mice by

\section{Figure 1}

Splenocyte and T cell transfer into nu/nu mice. (A) Total splenocytes from IL-1 Ra ${ }^{-/}$mice (filled circles, $n=10$ ) induced arthritis, while T cell-depleted splenocytes (open circles, $n=7$ ) did not induce arthritis in nu/nu mice. (B) Arthritic severity score of splenocyte-transferred mice. (C) Purified T cells from spleen and LNs of either arthritic (filled squares, $n=10$ ) or nonarthritic (open squares, $n=8$ ) IL-1 Ra ${ }^{-/}$mice induced arthritis in nu/nu mice, while T cells from WT mice (triangles, $n=11$ ) did not. (D) Arthritic severity score of T cell-transferred mice. (E-H) Histology of the ankle joints of WT (E) or IL-1Ra- ${ }^{-/}(\mathbf{F}-\mathrm{H}) \mathrm{T}$ celltransferred nu/nu mice. (G) Infiltration of inflammatory cells (indicated by arrowheads). (H) Erosive bone destruction by replacement of bone matrix with fibroblastic cells (indicated by arrowheads). Magnification, $\times 40(\mathbf{E}$ and $\mathbf{F}) ; \times 100(\mathbf{G}$ and $\mathbf{H})$. (I) Serum IgG (left) and RF (right) levels in WT T cell- or IL-1 Ra- ${ }^{-1}$ T cell-transferred nu/nu mice. The average in each group is shown as a horizontal bar. WT, WT donors $(n=10)$; KO+, arthritic-IL-1 $\mathrm{Ra}^{-1}$ donors $(n=10)$; KO-, nonarthritic IL-1Ra ${ }^{-/-}$donors $(n=8) .{ }^{*} P<0.05$. intercrossing them with scid/scid mice on the BALB/c background. While IL-1 $\mathrm{Ra}^{-/-} s c i d /+$ or IL-1 $\mathrm{Ra}^{-/-}+/+$mice showed a high incidence of arthritis, IL-1 $\mathrm{Ra}^{-/}$scid/scid mice failed to develop arthritis by 20 weeks of age (Table 1 ). These results suggest that combined deficiency of $\mathrm{T}$ and $\mathrm{B}$ cells completely suppresses the development of arthritis in IL-1 $\mathrm{Ra}^{-/}$mice.

Peripheral T cells from IL-1Ra-/- mice induced arthritis. We next examined the contribution of the specific cell types of the immune system to the development of arthritis by cell transfer experiments. When total splenocytes from IL-1Ra-/- mice were transferred into $n u / n u$ mice on the BALB/c background, these mice developed severe arthritis as early as 3 weeks after the cell transfer (Figure 1, A and B). On the other hand, when T cell-depleted splenocytes were transferred into $n u / n u$ mice, these mice did not develop arthritis at all. These results strongly suggest that $\mathrm{T}$ cells are involved in the development of arthritis. We further examined the effects of transplantation of purified T cells in the periphery. When T cells from spleens and LNs were transferred into $\mathrm{mu} / \mathrm{mu}$ mice, they developed severe arthritis as early as 2 weeks after transfer (Figure 1, $\mathrm{C}$ and $\mathrm{D})$. The disease status of the donor mice influenced these results; $T$ cells from arthritic mice were more efficient than those
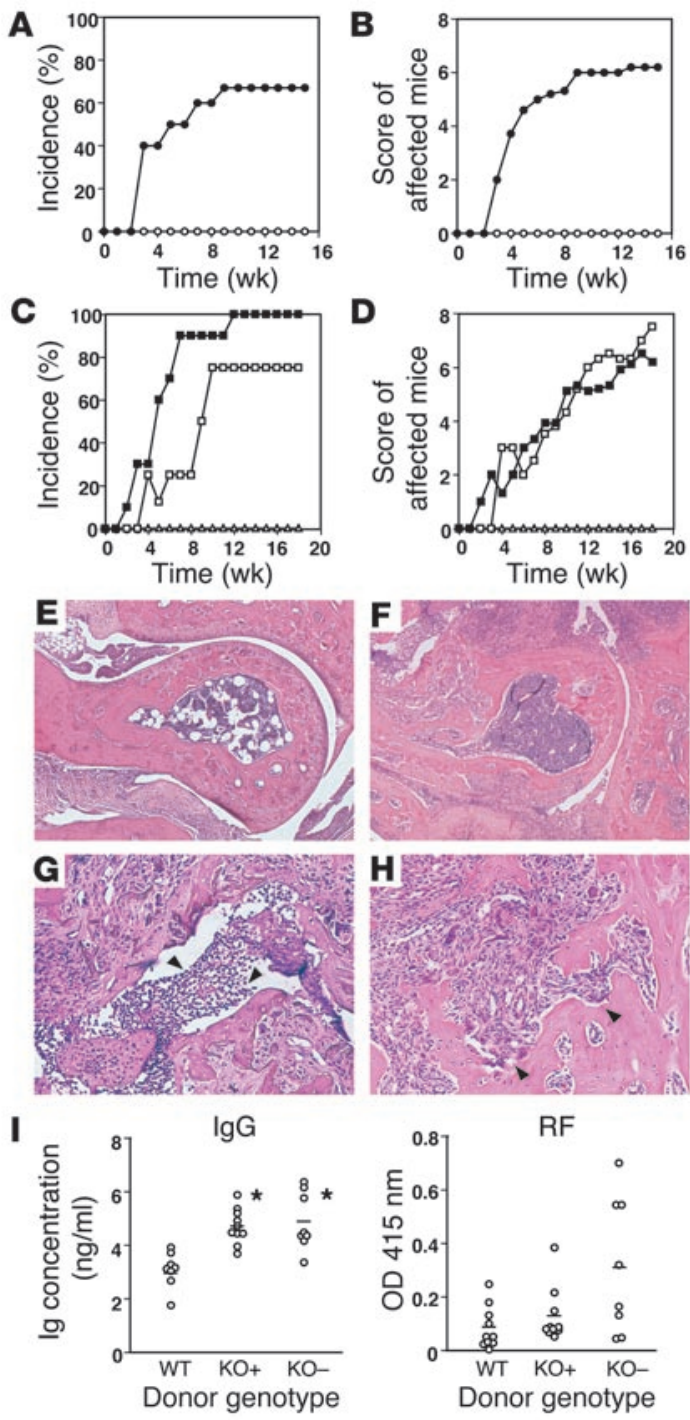

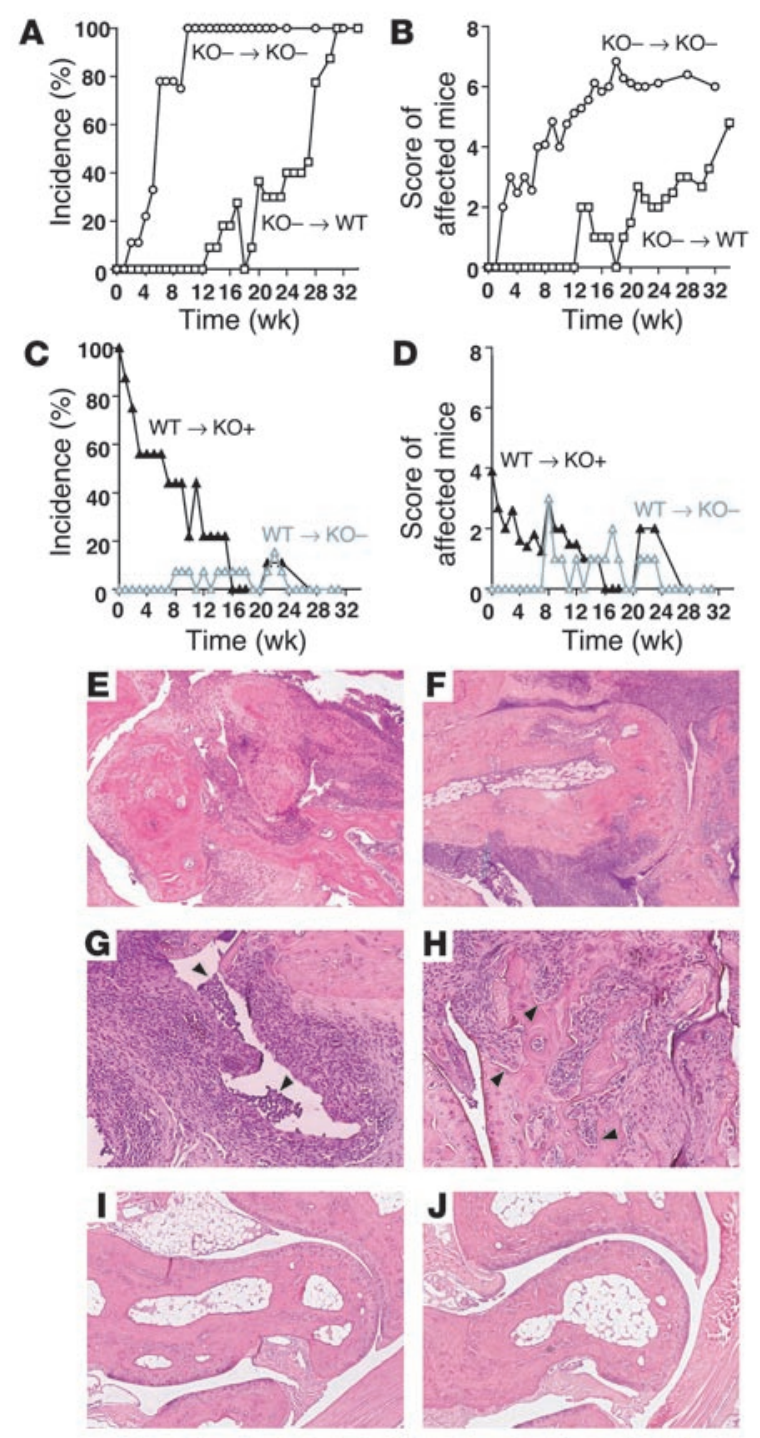

from nonarthritic mice in inducing arthritis in recipient mice (Figure 1C). However, cells from both arthritic and nonarthritic mice could induce the disease. Histological analyses revealed that arthritis was observed in both ankle and knee joints of IL-1 $\mathrm{Ra}^{-/-} \mathrm{T}$ cell-transferred $n u / n u$ mice (Figure 1, F-H and data not shown). Proliferation of synovial cells, infiltration of neutrophils and lymphocytes, and bone destruction were remarkable in both ankle and knee joints (Figure 1, E-H and data not shown). Serum IgG levels and RF levels were enhanced in IL-1 $\mathrm{Ra}^{-/-} \mathrm{T}$ cell-transferred $n u / n u$ mice compared with WT T cell-transferred mice, although the difference in RF levels was not statistically significant (Figure 1I). We also performed thymocyte transfer experiments to examine whether or not activation of IL-1 $\mathrm{Ra}^{-/-} \mathrm{T}$ cells before transplantation is necessary, and we found that thymocytes from IL-1 $\mathrm{Ra}^{-/}$mice induced arthritis in $n u / n u$ mice, but with lower frequency than that seen in mice transferred with splenocytes or purified $\mathrm{T}$ cells (IL-1 Ra ${ }^{-/}$- thymocyte-transferred mice, 46\%; WT thymocyte-transferred mice, $0 \%$ at 15 weeks). These results clearly indicate that $\mathrm{T}$ cells are required for the development of arthritis in IL-1 $\mathrm{Ra}^{-/-}$mice, and suggest that IL-1Ra-/- T cells can enhance immune responses against self components.

\section{Figure 2}

BM cell replacement between WT and IL-1Ra ${ }^{-/-}$mice. BM cells from $\mathrm{IL}-1 \mathrm{Ra}^{-/}$mice induced arthritis in WT mice, while those from WT mice suppressed arthritis in IL-1 $\mathrm{Ra}^{-/-}$mice. (A) Incidence of arthritis in IL-1 Ra ${ }^{-/}$BM cell-transferred WT (squares, $n=11$ ) or IL-1 $\mathrm{Ra}^{-/}$mice (circles, $n=9$ ). (B) Arthritic severity score of IL-1Ra-l- BM cell-transferred mice. (C) Incidence of arthritis in WT BM cell-transferred IL-1 Ra ${ }^{-1-}$ mice with (closed triangle, $n=9$ ) or without (open triangle, $n=13$ ) arthritis. (D) Arthritic severity score of WT BM-transferred IL-1 Ra ${ }^{-1-}$ mice. (E-H) Histopathology of the ankle joints of IL-1Ra ${ }^{-/-} \mathrm{BM}$ cell-transferred IL-1 Ra ${ }^{-/-}$mice $(E)$ and IL-1 Ra ${ }^{-/-}$BM cell-transferred WT mice $(\mathbf{F}-\mathbf{H})$ at the end of the experiments (32 weeks and 34 weeks after the cell transfer, respectively). (G) Infiltration of inflammatory cells (indicated by arrowheads) into articular space and proliferation of the lining cells of the synovial membrane. (H) Pannus formation and erosive destruction of the bone (indicated by arrowheads). (I and $\mathbf{J}$ ) Histology of the normal ankle joints of WT BM cell-transferred nonarthritic $\mathrm{IL}-1 \mathrm{Ra}^{-/}$mice (I) and arthritic IL-1 $\mathrm{Ra}^{-/-}$mice $(\mathrm{J})$ at 31 weeks after the cell transfer. Magnification, $\times 40(\mathbf{E}, \mathbf{F}, \mathbf{I}$, and $\mathbf{J}) ; \times 100(\mathbf{G}$ and $\mathbf{H})$.

BM-derived cells from IL-1Ra-/- mice induced arthritis in normal mice and those from normal mice suppressed the development of arthritis in $\mathrm{IL}-1 \mathrm{Ra}^{-/-}$mice. To examine whether abnormal T cell education or a stem cell disorder is responsible for the $\mathrm{T}$ cell abnormality seen in IL-1 $\mathrm{Ra}^{-/}$mice, we next reconstituted the immune system by BM cell transfers. BM cells were prepared from IL-1Ra- ${ }^{-/}$mice by treating these cells with anti-Thy-1.2 Ab to deplete $\mathrm{T}$ cells, and then they were transferred into the recipient mice that were lethally irradiated. Mice that received BM cells did not die, whereas those that did not receive BM cells died within 2 weeks. We observed the development of arthritis as early as 2 weeks after the transfer of 4-week-old IL-1 Ra-/- BM cells to nonarthritic IL-1 $\mathrm{Ra}^{-/-}$mice, which would normally develop arthritis at 5-8 weeks of age (Figure 2A). Arthritis was also observed in WT mice receiving IL-1 $\mathrm{Ra}^{-/}$BM cells. These mice developed arthritis, however, more than 3 months after the transfer, indicating that the genotype of recipient mice (WT or IL-1Ra-deficient) affects the incidence and severity of arthritis (Figure 2, A and B). Replacement of the recipient $\mathrm{BM}$ cells by the donor cells was confirmed by Southern blot analyses at the end of the experiments. Cells from lymphoid tissues such as the spleen and LNs consisted mainly of the donor cells, while those from joints showed both donor and recipient genotypes (data not shown), suggesting that only BM-derived cells were replaced in the joints (16). Histological analysis of the ankle joints showed synovial and periarticular inflammation with articular erosion in both WT and IL-1 $\mathrm{Ra}^{-/-}$mice that received IL-1 $\mathrm{Ra}^{-/}$BM cells (Figure 2, E and F). We observed proliferation of synovial lining cells and invasion of inflammatory cells, includ-

\section{Table 2}

Increased cytokine secretion by $\mathrm{CD}^{+}{ }^{+} \mathrm{T}$ cells from IL-1 $\mathrm{Ra}^{-1-}$ mice

\begin{tabular}{lccc} 
Cytokine & Detection limit & WT & IL-1Ra ${ }^{-/}$ \\
IFN- $\gamma(\mathrm{U} / \mathrm{ml})$ & $20 \mathrm{U} / \mathrm{ml}$ & $59.7 \pm 13.0$ & $153.8 \pm 19.1^{\mathrm{A}}$ \\
$\mathrm{IL}-4(\mathrm{pg} / \mathrm{ml})$ & $10 \mathrm{pg} / \mathrm{ml}$ & $42.0 \pm 5.0$ & $161.9 \pm 3.2^{\mathrm{A}}$ \\
TNF- $\alpha(\mathrm{pg} / \mathrm{ml})$ & $12.5 \mathrm{pg} / \mathrm{ml}$ & $52.0 \pm 7.8$ & $95.3 \pm 3.7^{\mathrm{A}}$ \\
\hline
\end{tabular}

Purified CD4 ${ }^{+} \mathrm{T}$ cells were stimulated with $1 \mu \mathrm{g} / \mathrm{ml}$ (IFN- $\gamma$ and IL-4) or $10 \mu \mathrm{g} / \mathrm{ml}$ (TNF- $\alpha$ ) of plate-coated anti-CD3 mAb for 48 hours. Data are expressed as mean \pm SEM $(n=4)$. ${ }^{A} P<0.01$ by Student's $t$ test. Similar results were obtained from 2 independent experiments. 


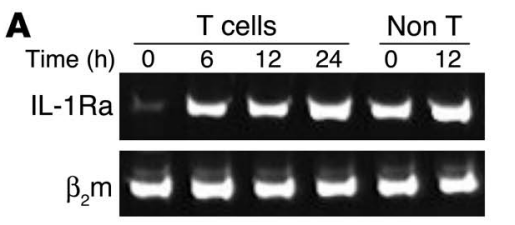

B

D
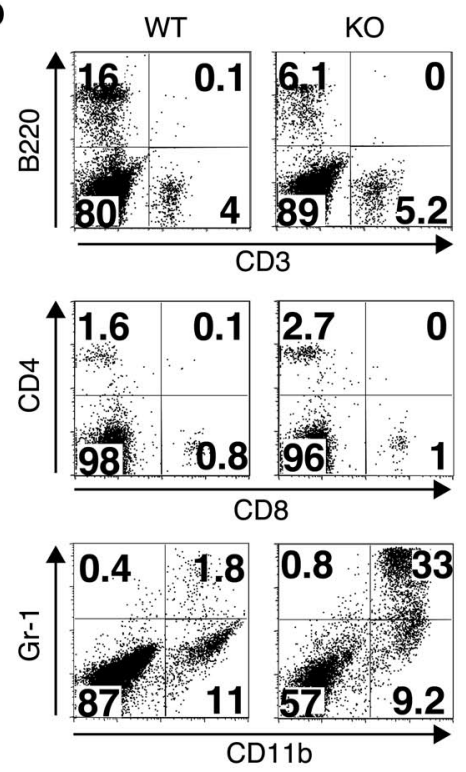

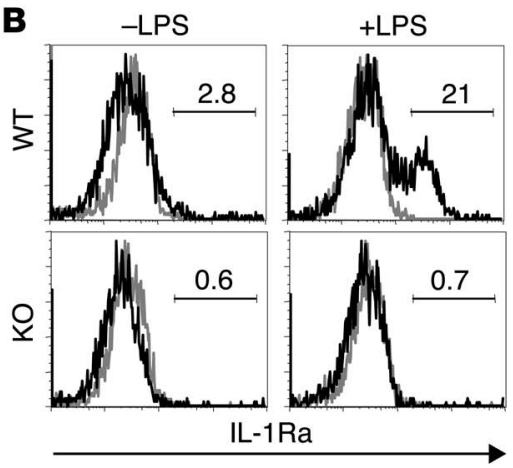

C
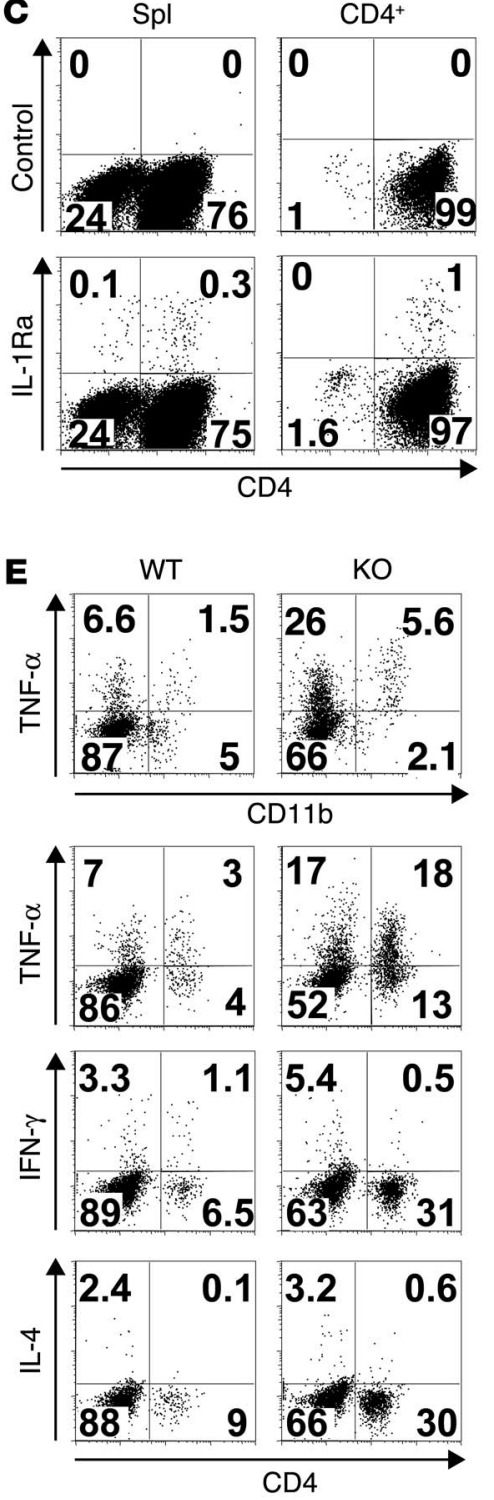

Figure 3

IL-1Ra and cytokine production. (A) IL-1Ra mRNA expression in WT T cells. Purified T cells from WT mice were stimulated with $10 \mu \mathrm{g} / \mathrm{ml}$ of plate-coated antiCD3 mAb for $0,6,12$, or 24 hours, and IL-1Ra mRNA levels were determined by RT-PCR. T cell-depleted splenocytes (Non T) were stimulated with $5 \mu \mathrm{g} / \mathrm{ml}$ LPS for 0 and 12 hours as controls. $\beta_{2} \mathrm{~m}$ is used as an internal control. (B) Intracellular staining for IL-1Ra in PECs. PECs from WT and IL-1 $\mathrm{Ra}^{-/-}$mice were stimulated with LPS, and IL-1Ra+ cells in the CD11b+ population are shown as histograms. Black-lined histograms: staining with IL-1Ra Ab. Gray-lined histograms: staining with isotype control Ig. Percentages of IL-1Ra+ cells are indicated. (C) Intracellular staining for IL-1Ra in splenocytes (Spl) and CD4 ${ }^{+} \mathrm{T}$ cells from WT mice after stimulation with anti-CD3 mAb. Upper panels show staining with isotype control Ig and lower panels show staining with anti-IL-1Ra Ab. (D) Expression of cell lineage-specific surface molecules on cells from ankle joints of WT and $\mathrm{IL}-1 \mathrm{Ra}^{-1-}$ (KO) mice. B220, Gr-1, and CD11b are markers for B cells, granulocytes (including neutrophils), and macrophages, respectively. (E) Intracellular staining for cytokines in cells from the ankle joints of WT and $\mathrm{IL}-1 \mathrm{Ra}^{-/}$mice. Joint-derived cells were stimulated with $10 \mathrm{ng} / \mathrm{ml} \mathrm{PMA}$ and $400 \mathrm{ng} / \mathrm{ml}$ ionomycin for 6 hours with $2 \mu \mathrm{M}$ monensin. Similar results were obtained in 3 independent experiments.

Enhanced cytokine production from activated $T$ cells in $I L-1 \mathrm{Ra}^{-/-}$mice. Since our results suggested abnormal $\mathrm{T}$ cell function in IL-1 $\mathrm{Ra}^{-/}$mice, we next analyzed $\mathrm{T}$ cell proliferation and cytokine production upon TCR stimulation. Proliferative responses of T cells from IL-1 $\mathrm{Ra}^{-/-}$mice stimulated with anti-CD3 mAb were normal (data not shown). However, these $\mathrm{T}$ cells produced much higher levels of IFN- $\gamma$, IL-4, and TNF- $\alpha$ in the culture supernatant than did those from WT mice (Table 2 ). These results suggest that IL-1 $\mathrm{Ra}^{-/-} \mathrm{T}$ cells produce higher levels of cytokines upon TCR stimulation.

We also examined IL-1Ra expression in normal WT T cells by RT-PCR, ELISA, and intracellular staining. Unstimulated T cells expressed low levels of $I L-1 R a$

ing lymphocytes and neutrophils (Figure 2, E-G). Bone erosion and pannus formation were also remarkable (Figure $2 \mathrm{H}$ ).

To examine whether normal stem cells can suppress the development of arthritis in IL-1 $\mathrm{Ra}^{-/-}$mice, we prepared BM cells from WT mice and transferred them into irradiated nonarthritic or arthritic IL-1 $\mathrm{Ra}^{-/}$mice. Development of arthritis was suppressed in nonarthritic IL-1 $\mathrm{Ra}^{-/}$mice that received normal BM cells (Figure 2, C and D). Arthritis was also ameliorated in arthritic IL-1 $\mathrm{Ra}^{-/-}$mice that received normal BM cells (Figure 2, C and D). At 31 weeks after transfer of BM cells, joint pathology was examined histologically. Nonarthritic IL-1 $\mathrm{Ra}^{-/-}$mice that received normal BM cells showed no sign of arthritis (Figure 2I). Moreover, arthritic IL-1 $\mathrm{Ra}^{-/-}$mice that received normal BM cells showed complete recovery from arthritis (Figure 2J). Thus, replacement of the BM-derived cells in IL-1 $\mathrm{Ra}^{-/-}$mice with those of normal mice can suppress and actually reverse the development of arthritis in IL-1 $\mathrm{Ra}^{-/-}$mice. These results indicate that BM-derived cells themselves are abnormal in IL-1 $\mathrm{Ra}^{-/-}$mice.
mRNA, but upon stimulation through TCR, IL-1Ra mRNA expression was upregulated (Figure $3 \mathrm{~A}$ ). We also observed secretion of the IL-1Ra protein in the culture supernatant of WT purified CD4+ $\mathrm{T}$ cells (>99\% purity) after anti-CD3 mAb stimulation $(20-40 \mathrm{pg} / \mathrm{ml}$ at 72-96 hours), indicating that $T$ cells can produce and secrete the IL-1Ra protein. To confirm the IL-1Ra protein production from $\mathrm{T}$ cells directly, we stained stimulated $\mathrm{CD}^{+} \mathrm{T}$ cells intracellularly with anti-IL-1Ra Ab. As a control experiment for the staining, we first stained peritoneal exudate cells (PECs) from WT or IL-1 $\mathrm{Ra}^{-/-}$mice stimulated with or without LPS, and showed that the staining specifically detected IL-1Ra after the stimulation (Figure 3B). Then, purified $\mathrm{CD}^{+} \mathrm{T}$ cells from BALB/c WT mice were stimulated with plate-coated anti-CD3 mAb and stained for the intracellular IL-1Ra protein. As shown in Figure 3C, CD4 ${ }^{+} \mathrm{T}$ cells can produce IL-1Ra protein after TCR stimulation. These IL-1Ra-producing cells were different from those which produce IFN- $\gamma$, IL-4, or IL-10 under these conditions (data not shown). These results indicate that IL-1Ra is produced by $\mathrm{T}$ cells and may regulate $\mathrm{T}$ cell activation by IL-1. 

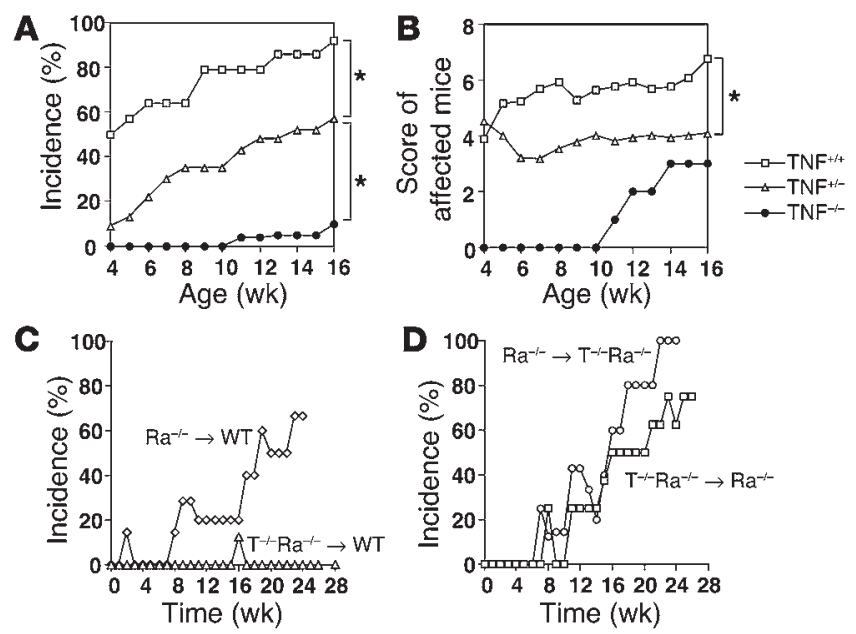

Figure 4

Incidence of arthritis in TNF- $\alpha$-deficient IL-1Ra ${ }^{-/-}$mice. Incidence (A) and severity score (B) of arthritis in TNF- $\alpha$-deficient IL-1 Ra ${ }^{-/}$mice. Squares, TNF- $\alpha^{+/+} \mathrm{IL}-1 \mathrm{Ra}^{-/-}$mice $(n=14)$; triangles, TNF- $\alpha^{+/-} \mathrm{IL}-1 \mathrm{Ra}^{-/}$ mice $(n=23)$; circles, TNF- $\alpha^{-/-} \mathrm{IL}-1 \mathrm{Ra}^{-/-}$mice $(n=23)$. Statistical significance between genotypes was calculated by repeated-measures ANOVA or two-way ANOVA. ${ }^{*} P<0.01$. (C) Incidence of arthritis in TNF- $\alpha^{-1-} \mathrm{IL}-1 \mathrm{Ra}^{-/-}\left(\mathrm{Ra}^{-1-}\right)$ or IL-1 Ra- ${ }^{-1}$ BM cell-transferred WT mice. Triangles, WT mice transferred with TNF- $\alpha^{-1-} \mathrm{IL}-1 \mathrm{Ra}^{-/-} \mathrm{BM}$ cells $\left(\mathrm{T}^{-/-} \mathrm{Ra}^{-/-} \rightarrow \mathrm{WT}\right)$; diamonds, WT or heterozygous (IL-1 $\mathrm{Ra}^{+-}$) mice transferred with IL-1Ra ${ }^{-/-}$BM cells $\left(\mathrm{Ra}^{-/-} \rightarrow \mathrm{WT}\right)$. (D) Incidence of arthritis in TNF- $\alpha^{-/-} \mathrm{IL}-1 \mathrm{Ra}^{-/-}$or IL-1 $\mathrm{Ra}^{-/-} \mathrm{BM}$ cell-transferred IL-1 $\mathrm{Ra}^{-/-}$ mice. Squares, IL-1 $\mathrm{Ra}^{-/}$mice transferred with TNF- $\alpha^{-/} \mathrm{IL}-1 \mathrm{Ra}^{-/} \mathrm{BM}$ cells $\left(\mathrm{T}^{-/-} \mathrm{Ra}^{-/-} \rightarrow \mathrm{Ra}^{-/}\right)$; circles, TNF- $\alpha^{-1-} \mathrm{IL}-1 \mathrm{Ra}^{-/-}$mice transferred with IL-1 Ra ${ }^{-/}$BM cells $\left(\mathrm{Ra}^{-/-} \rightarrow \mathrm{T}^{-/-} \mathrm{Ra}^{-/-}\right)$.

Identification of cells in the joints and cellular cytokine production. To further analyze the roles of cytokines overexpressed in IL-1Ra-/$\mathrm{T}$ cells, we examined the local subsets of lymphocytes and their cytokine production in the joints. The ankle joints were dissected, and cytokine production in the joint cells was examined by intracellular staining. The total cell number in the ankle joints was increased 2 -fold in IL-1 $\mathrm{Ra}^{-/-}$mice $\left(7.1 \times 10^{6}\right.$ cells per mouse, $n=10)$ compared to WT mice $\left(3.7 \times 10^{6}\right.$ cells per mouse, $\left.n=10\right)$, suggesting infiltration of inflammatory cells. Thus, although the proportion of $\mathrm{T}$ cells was not dramatically increased (Figure 3D), the total $\mathrm{T}$ cell numbers in the joints of IL-1 $\mathrm{Ra}^{-/-}$mice were greater than in WT mice. In the T lymphocyte subsets, $\mathrm{CD}^{+}{ }^{+}$cells were detected more frequently than $\mathrm{CD}^{+}$cells, consistent with our previous observations (17). We also observed increased infiltration of $\mathrm{CD} 1 \mathrm{~b}^{+} \mathrm{Gr}-1^{+}$cells, most likely activated neutrophils, in the arthritic joints of IL-1 $\mathrm{Ra}^{-/-}$mice (Figure 3D).

Cells from the ankle joints were stimulated with PMA and ionomycin to examine the ability to produce cytokines such as TNF- $\alpha$, IFN- $\gamma$, and IL-4. As shown in Figure 3E, most of the IL-1 Ra ${ }^{-/-}$ $\mathrm{CD}_{11} \mathrm{~b}^{+}$cells produced TNF- $\alpha$. Some of CD $4^{+} \mathrm{T}$ cells in the joints were also TNF- $\alpha$-producing cells. Moreover, many more of these cells were found in the IL-1Ra-- joints, suggesting that the infiltrating $\mathrm{CD}^{+} \mathrm{T}$ cells in arthritic joints may produce more TNF- $\alpha$ and enhance inflammation. Only a small percentage of cells in the joints produced IFN- $\gamma$ or IL- 4 in either WT mice or IL-1 Ra ${ }^{-/-}$mice.

Suppression of arthritis in TNF- $\alpha$-deficient IL-1Ra-/- mice. We previously reported that high levels of inflammatory cytokines, including TNF- $\alpha$, were detected in the joints of IL-1 $\mathrm{Ra}^{-/-}$mice
(9). We also observed TNF- $\alpha$-producing cells in the ankle joints of these mice (Figure 3E). Furthermore, we detected high levels of TNF- $\alpha$ in the culture of IL-1 Ra- ${ }^{-1}$ T cells (Table 2 ). To elucidate the role of TNF- $\alpha$ in the development of arthritis in IL-1 Ra-/mice, we generated TNF- $\alpha$ and IL-1Ra double-deficient mice by crossing IL-1 $\mathrm{Ra}^{-/-}$mice with TNF- $\alpha^{-/-}$mice.

As shown in Figure 4, A and B, homozygous TNF- $\alpha$ deficiency strongly suppressed development of arthritis in IL-1Ra-/- mice. An intermediate, but significant, suppression was observed in mice heterozygous for the TNF- $\alpha$ gene, suggesting a TNF- $\alpha$ gene dosage effect on the incidence and severity of arthritis. Histological analyses revealed that TNF- $\alpha^{-/-}$IL-1 $\mathrm{Ra}^{-/-}$mice that appeared normal also showed normal joint histology, but those with swollen joints showed arthritic pathology of inflammation and bone destruction similar to that seen in IL-1 $\mathrm{Ra}^{-/}$mice (data not shown). These results suggest that TNF- $\alpha$ plays critical roles in the development of arthritis in IL-1 $\mathrm{Ra}^{-/-}$mice.

However, since the TNF- $\alpha$ gene is located in the MHC locus and mice deficient for this gene were produced on the 129 background $\left(\mathrm{H}-2^{\mathrm{b}}\right)$, TNF- $\mathrm{\alpha}^{-/-}$mice backcrossed to the BALB/c strain $\left(\mathrm{H}-2^{\mathrm{d}}\right)$ for 8 generations still had the same $\mathrm{H}-2$ locus as the 129 mice. To examine the contribution of the MHC locus in the development of arthritis in IL-1Ra-/- mice, IL-1 $\mathrm{Ra}^{-/-}$mice were crossed with the BALB.B congenic for the C57BL/6 H-2 locus $\left(\mathrm{H}-2^{\mathrm{b}}\right)$ or the B10.D2/ $\mathrm{n}$ congenic for the BALB/c H-2 locus. The results clearly argued that $\mathrm{MHC}$ differences were not responsible for the suppression of arthritis in TNF- $\alpha^{-/-}$mice (data not shown).

To further analyze the role of TNF- $\alpha$ in the development of arthritis in IL-1Ra-/- mice, we examined the effects of TNF- $\alpha$ deficiency in BM cell transfer experiments. BM cells from TNF- $\alpha^{-/-} \mathrm{IL}^{-1 \mathrm{Ra}^{-/}}$mice did not induce arthritis in WT mice up to 30 weeks after transfer, while BM cells from IL-1Ra ${ }^{-/-}$mice induced arthritis in WT mice starting after 8 to 12 weeks (Figures $2 \mathrm{~A}$ and $4 \mathrm{C}$ ). On the other hand, TNF- $\alpha^{-/-}$IL-1 $\mathrm{Ra}^{-/-}$BM cells transferred into IL-1 $\mathrm{Ra}^{-/-}$mice induced arthritis, and IL-1 $\mathrm{Ra}^{-/-}$BM cells transferred into TNF- $\alpha^{-/-} \mathrm{IL}-1 \mathrm{Ra}^{-/-}$ mice also induced arthritis (Figure 4, C and D). These results suggest that TNF- $\alpha$ produced by both BM-derived cells and non-BMderived cells plays an important role in the development of arthritis
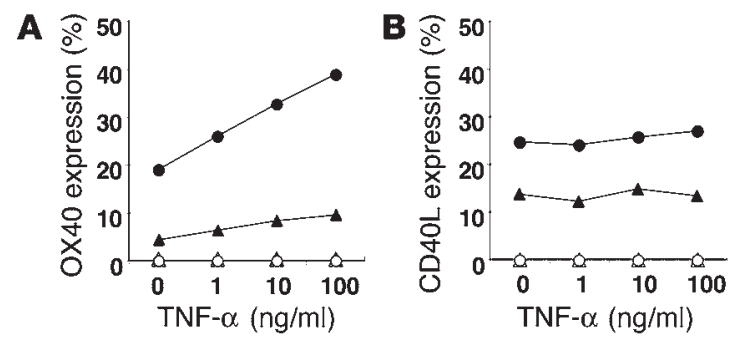

\section{Figure 5}

Induction of OX40 expression on T cells by TNF- $\alpha$. (A) OX40 expression (\%) on $\mathrm{CD}^{+} \mathrm{T}$ cells stimulated with plate-coated anti-CD3 $\mathrm{mAb}$ $(0.1$ or $0.3 \mu \mathrm{g} / \mathrm{ml})$ plus TNF- $\alpha(0,1,10$, or $100 \mathrm{ng} / \mathrm{ml})$ for 72 hours. Open symbols: control Ig staining. Filled symbols: anti-OX40 Ab staining for $0.1 \mu \mathrm{g} / \mathrm{ml}$ (triangles) or $0.3 \mu \mathrm{g} / \mathrm{ml}$ (circles) of anti-CD3 mAb stimulation. (B) CD40L expression (\%) on CD4+ $\mathrm{T}$ cells stimulated with plate-coated anti-CD3 mAb $(0.1$ or $0.3 \mu \mathrm{g} / \mathrm{ml})$ plus TNF- $\alpha(0,1,10$, or $100 \mathrm{ng} / \mathrm{ml}$ ) for 24 hours. Open symbols: control lg staining. Filled symbols: anti-OX40 Ab staining for $0.1 \mu \mathrm{g} / \mathrm{ml}$ (triangles) or $0.3 \mu \mathrm{g} / \mathrm{ml}$ (circles) of anti-CD3 mAb stimulation. Similar results were obtained in 5 independent experiments. 

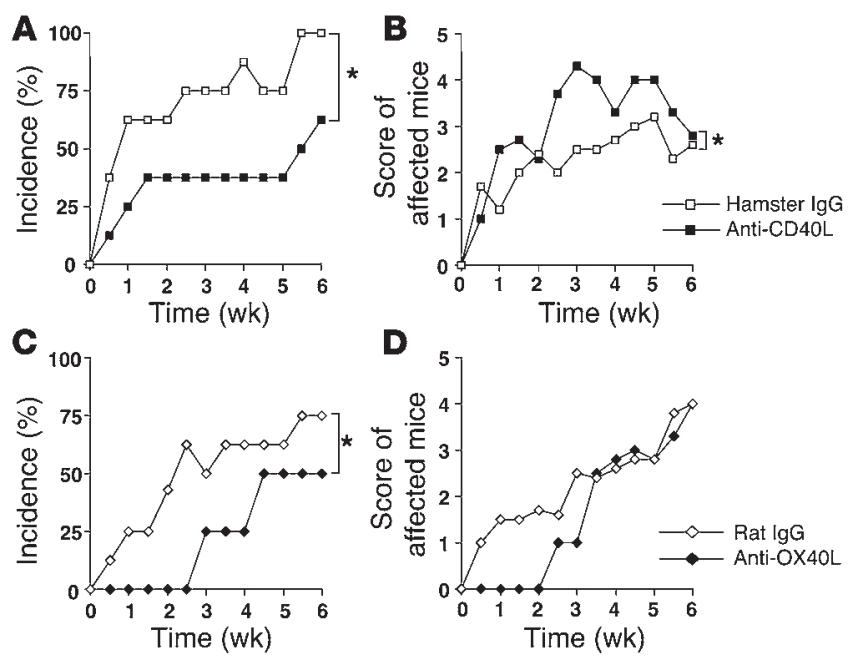

Figure 6

Anti-CD40L or anti-OX40L Ab treatment of IL-1 $\mathrm{Ra}^{-/-}$mice. Blocking Abs against either CD40L or OX40L were administrated to IL-1 Ra ${ }^{-/}$ mice before the onset of arthritis. Ab treatment was continued twice a week for 6 weeks, and incidence of arthritis was inspected each time before $\mathrm{Ab}$ administration. Incidence and severity score of arthritis in control hamster IgG-treated (open squares, $n=8$ ) or anti-CD40L Ab-treated (filled squares, $n=8$ ) IL-1 Ra ${ }^{-/}$mice ( $\mathbf{A}$ and $\mathbf{B}$ ) and those in control rat IgG-treated (open diamonds, $n=8$ ) or anti-OX40L Abtreated (closed diamonds, $n=8) \mathrm{IL}-1 \mathrm{Ra}^{-/}$mice $(\mathbf{C}$ and $\mathbf{D})$. ${ }^{*} P<0.01$ by repeated-measures ANOVA or 2-way ANOVA.

in IL-1 $\mathrm{Ra}^{-/}$mice. Since TNF- $\alpha$ is crucial for the development of arthritis in this model, these results suggest that TNF- $\alpha$ can be produced in the IL-1 $\mathrm{Ra}^{-/-}$recipient mice from relatively $\gamma$-ray-resistant cells such as macrophages or type A synovial cells.

TNF- $\alpha$ induced expression of OX40, but not CD40L, on T cells. We recently showed that IL-1 produced by APCs induces CD40L and OX40 expression on T cells (15). It has also been reported that ligation between CD40 on APCs and CD40L on T cells leads to TNF- $\alpha$ production from APCs (13). Here we examined the possible involvement of TNF- $\alpha$ in the induction of CD40L and OX40 on T cells. When $\mathrm{CD}^{+} \mathrm{T}$ cells from WT mice were stimulated with varying concentrations of TNF- $\alpha(1-100 \mathrm{ng} / \mathrm{ml})$ together with plate-coated anti-CD3 $\mathrm{mAb}(0-1 \mu \mathrm{g} / \mathrm{ml})$, the higher concentrations of TNF- $\alpha$ upregulated OX40 expression (Figure 5A), but not CD40L expression, on T cells (Figure 5B). These results suggest that TNF- $\alpha$ may contribute to the development of arthritis in IL-1 $\mathrm{Ra}^{-/}$mice through the induction of OX40 expression on T cells. However, at the highest concentration of anti-CD $3 \mathrm{mAb}(1 \mu \mathrm{g} / \mathrm{ml})$, maximal expression of OX40 could occur independent of TNF- $\alpha$ (data not shown).

Involvement of CD40-CD40L and/or OX40-OX40L pathways in the development of arthritis. To explore the contribution of CD40-CD40L and OX40-OX40L pathways to the pathogenesis of arthritis, we injected blocking $\mathrm{Abs}$ for these molecules into IL-1 Ra ${ }^{-/-}$mice. Abs for either CD40L or OX40L were injected into IL-1 $\mathrm{Ra}^{-/-}$mice for 6 weeks, starting from before onset of the disease, and incidence of arthritis was monitored during the administration period. As shown in Figure 6, Abs for both CD40L and OX40L were able to partially suppress development of arthritis in IL-1 Ra-/- mice. The incidence of arthritis was lower in mice treated with anti-CD40L $\mathrm{Ab}$ than in those treated with control $\mathrm{Ab}$ (hamster IgG) (Figure $6 \mathrm{~A})$. The induction of arthritis was delayed in mice treated with
anti-OX40L Ab, and the incidence of arthritis after 6 weeks was lower than in mice treated with control Ab (rat IgG) (Figure 6C). However, once arthritis was induced, antibody treatment was ineffective. The severity score of affected mice was similar in antiOX40L-treated mice and control Ab-treated mice, and severity was actually exacerbated in mice treated with anti-CD40L Ab (Figure $6, \mathrm{~B}$ and $\mathrm{D})$. Thus, these results suggest that both the CD40CD40L and OX40-OX40L pathways are involved in development of arthritis in IL-1 $\mathrm{Ra}^{-/-}$mice.

\section{Discussion}

In this study, we have shown that the development of arthritis in IL-1 $\mathrm{Ra}^{-/}$mice is completely suppressed in scid/scid mice and that IL-1 $\mathrm{Ra}^{-/} \mathrm{T}$ cell transfers induce arthritis in $n u / n u$ mice, suggesting a crucial role of $\mathrm{T}$ cells in the pathogenesis of arthritis in this model (Table 1 and Figure 1). T cells from arthritic IL-1Ra ${ }^{-/}$mice induced arthritis more efficiently than those from nonarthritic mice, suggesting that arthritogenic-activated and/or memory $\mathrm{T}$ cells are generated in IL-1 $\mathrm{Ra}^{-/}$mice and involved in the development of arthritis. However, cells from both arthritic and nonarthritic IL-1 $\mathrm{Ra}^{-/-}$mice were able to induce arthritis, supporting a $\mathrm{T}$ cell intrinsic defect. Interestingly, donor T cells from IL-1 $\mathrm{Ra}^{-/-}$mice are not necessarily primed by autoantigens, because naive $T$ cells from thymus could induce arthritis, although this took longer than with peripheral $\mathrm{T}$ cells that may have been preactivated. With regard to this, we have previously shown that IL-1 from APCs can activate T cells through the induction of CD40L and OX40 on T cells (15), and in the absence of IL-1Ra, even physiological levels of IL-1 activate T cells excessively, resulting in the development of autoimmunity (9). Our present data suggest that T cell-derived IL-1Ra also regulates $T$ cell activity in an autocrine manner, although IL-1Ra is known to be produced by many other types of cells, including monocytes and macrophages in the synovial lining layer. In support of this notion, $I L-1 R a$ mRNA expression was observed in unstimulated T cells at low levels but stronger expression was induced in activated $\mathrm{T}$ cells (Figure 3A). Thus, naive IL-1 $\mathrm{Ra}^{-/-} \mathrm{T}$ cells transferred into $\mathrm{nu} / \mathrm{nu}$ mice may be activated excessively by the endogenous physiological levels of IL-1 which are constitutively expressed in the joints (9), thereby becoming reactive against synovial components.

We showed that transplantation of IL-1 $\mathrm{Ra}^{-/-} \mathrm{BM}$ cells induced arthritis in WT mice, and conversely, introduction of WT BM cells into IL-1 Ra-/- mice completely suppressed the disease, indicating that BM cells and their derivatives are abnormal in IL-1 $\mathrm{Ra}^{-/-}$mice (Figure 2). Since T cell progenitors are derived from BM cells, these observations are consistent with the notion that $\mathrm{T}$ cell dysfunction contributes to the development of autoimmunity. It should be noted, however, that WT mice that received IL-1 $\mathrm{Ra}^{-/-} \mathrm{BM}$ cells took longer to develop arthritis than did nonarthritic IL-1 Ra-/mice that received the same BM cells. Thus, not only the donor $\mathrm{BM}$ cells, but also the recipient milieu, seems to be involved in the development of arthritis, suggesting that IL-1Ra from relatively radiation-resistant cells also plays a role. Since the time required for developing arthritis in WT mice that receive IL-1 Ra-/- BM cells (3-4 months) is long enough to replace all the BM-derived cells in the recipient mice including the macrophages and type A synovial lining cells in the joint with donor type cells (16), this observation suggests that these late replacing components are involved in the development of arthritis. The observation that it took more than 16 weeks for arthritic IL-1 $\mathrm{Ra}^{-/-}$mice that received normal BM cells to recover from the disease also supports this idea. 
We have shown that the development of arthritis is completely suppressed in TNF- $\alpha^{-/-}$mice, indicating a crucial role for TNF- $\alpha$ in the pathogenesis of RA (Figure 4). In this context, a dominant role of TNF- $\alpha$ in the pathogenesis of RA has been demonstrated by recent clinical trials using anti-TNF- $\alpha \mathrm{Ab}$ and studies in the mouse using the CIA model $(3,18,19)$. It was also reported that transgenic mice carrying the TNF- $\alpha$ gene or mice deficient for the TNF- $\alpha$ AU-rich element (TNF $\triangle \mathrm{ARE}$ ), which produce higher amounts of the TNF- $\alpha$ protein, develop arthritis spontaneously $(7,8)$. However, since TNF ${ }^{\triangle A R E}$ mice develop arthritis even in the absence of mature lymphocytes (8), cells in the innate immune system such as neutrophils, macrophages, and mast cells, rather than the $\mathrm{T}$ cell-dependent immune system, have been suggested to be involved in the pathogenesis of this arthritis. Likewise, it has also been reported that inflammatory cytokines such as IL-1 and TNF- $\alpha$, but not IL- 6 , play critical roles in the effector phase of the disease in the $\mathrm{K} / \mathrm{BxN}$ model, in which arthritis can be induced by serum transfer (20). The effect of TNF- $\alpha$ deficiency, however, was not as strong in the CIA and $\mathrm{K} / \mathrm{BxN}$ models compared to that seen in the IL-1 Ra ${ }^{-/}$mice. Thus, the IL-1Ra ${ }^{-/}$mouse is one of the most sensitive models to the effects of TNF- $\alpha$.

Cell transfers showed that TNF- $\alpha^{-/-}$IL-1 $\mathrm{Ra}^{-/-}$BM cells could not induce arthritis in WT recipient mice, indicating that BM-derived cells are responsible for the production of TNF- $\alpha$ that is crucial for the development of arthritis. Nonetheless, it is interesting that TNF- $\alpha^{-/-}$IL-1Ra ${ }^{-/-}$BM cells could induce arthritis in IL-1Ra-/recipient mice but not in WT recipient mice. With regard to this, TNF- $\alpha$ expression is augmented in IL-1 $\mathrm{Ra}^{-/-}$mouse joints and this TNF- $\alpha$ may compensate for the deficiency in BM-derived cells. It is known that $\mathrm{T}$ cells are sensitive to irradiation and synovial lining cells are relatively resistant to irradiation, but some of the synovial lining cells such as the type A cells are of BM origin and are eventually replaced by donor cells after BM cell transplantation. Our results suggest that TNF- $\alpha$ is produced by these synovial lining cells in recipient IL-1 $\mathrm{Ra}^{-/-}$mice (Figure $3 \mathrm{E}$ ). This TNF- $\alpha$ may contribute to the arthritogenic milieu observed in IL-1 $\mathrm{Ra}^{-/-}$mice in the IL-1Ra-/- BM cell transfer experiments. Although some CD4 ${ }^{+}$ $\mathrm{T}$ cell populations produce TNF- $\alpha$, it is unlikely that TNF- $\alpha$ produced by these cells is the only source of TNF- $\alpha$ involved in the pathogenesis because, if that were true, TNF- $\alpha^{-/-} \mathrm{IL}_{-1 \mathrm{Ra}^{-/-} \mathrm{BM}}$ cells would not have induced arthritis even in $\mathrm{IL}-1 \mathrm{Ra}^{-/-}$recipient mice. However, since activated IL-1 Ra ${ }^{-/-} \mathrm{T}$ cells produce high amounts of TNF- $\alpha$ (Table 2 and Figure 3E), it seems likely that T cell-derived TNF- $\alpha$ also contributes to the development of arthritis. Transfer of TNF- $\alpha^{-/-}$IL-1 Ra ${ }^{-/-}$T cells into $n u / n u$ mice will help evaluate this possibility, although we were not able to address this question because of the difference in the MHC locus between the TNF- $\alpha^{-/-}$and $n u / n u$ mice.

We previously showed that IL-1 plays an important role in enhancing $\mathrm{T}$ cell-APC interactions by inducing CD40L and OX40 on T cells, and CD40L and OX40 expression were enhanced in $\mathrm{T}$ cells stimulated with antigen-bearing IL-1 $\mathrm{Ra}^{-/}$ APCs compared to WT APCs (15). It is known that ligation of CD40 on APCs with CD40L induces OX40L expression and TNF- $\alpha$ production by APCs $(13,14)$. Here, we have shown that TNF- $\alpha$ induces OX40 expression on T cells (Figure 5A). Thus, the mechanism for $\mathrm{T}$ cell activation by IL-1 is proposed as follows. Upon interaction with antigens, APCs produce IL-1, and IL-1 activates $\mathrm{T}$ cells, resulting in the induction of CD40L. Then, the CD40LCD40 interaction activates APCs to produce TNF- $\alpha$. This TNF- $\alpha$ induces OX40 on T cells, leading to enhancement of cytokine production and activation of $\mathrm{B}$ cells.

IL-17 plays important roles in inflammatory diseases such as arthritis, contact hypersensitivity, asthma, and delayed-type hypersensitivity (21-23). It was recently reported that a minor subpopulation of activated $\mathrm{CD}^{+} \mathrm{T}$ cells produces both TNF- $\alpha$ and IL-17 (24) and acts in synergy or additively with TNF- $\alpha$ and IL-1 by enhancing their production and action (25). We recently found that IL-17 production from IL-1 $\mathrm{Ra}^{-/} \mathrm{T}$ cells was induced by OX40 activation, and that IL-17-deficiency completely suppressed development of arthritis in IL-1 $\mathrm{Ra}^{-/-}$mice (17). Thus, it is possible that increased OX40 expression on T cells by TNF- $\alpha$ may induce production of IL-17, resulting in exacerbated inflammation.

We show here that blocking CD40-CD40L and OX40-OX40L interactions inhibited the development of arthritis in IL-1 Ra-/mice (Figure 6). These results suggest that blocking molecules downstream of IL- 1 and TNF- $\alpha$ in T cell activation may be effective to inhibit development of arthritis in IL-1 $\mathrm{Ra}^{-/-}$mice. However, our results showed that once arthritis started, treatment with antibody to CD40L actually exacerbated the progression of the disease (Figure 6B). It was recently reported that activation of CD40-expressing cells has a beneficial effect on the treatment of chronic CIA (26), indicating that not only inhibition of CD40-CD40L interactions, but also CD40 ligation, can be used to reduce the autoimmune inflammatory response. Consistent with this observation, an aggressive form of polyarthritis was described in a patient with a point mutation in the CD4OL gene (27). Thus, the CD40-CD40L system may play dual functions in the development of arthritis, and blocking the CD40-CD40L interaction by antibody treatment may also prevent beneficial effects of CD40 expression, resulting in exacerbated inflammation in IL-1 $\mathrm{Ra}^{-/-}$ mice after onset of the disease.

In summary, we have found a novel $\mathrm{T}$ cell regulatory mechanism in which IL-1Ra produced by T cells acts on T cells in an autocrine manner. We also showed that IL-1-induced TNF- $\alpha$ is crucial for the development of arthritis in IL-1Ra-/- mice and that this TNF- $\alpha$ induces OX40 on T cells. Furthermore, we showed that inhibition of either TNF- $\alpha$ or OX 40 function is effective to suppress the development of arthritis, providing a clue for the development of new therapies for RA.

\section{Methods}

Mice. IL-1 Ra-/-mice were produced as described (28). TNF- $\alpha^{-/-}$mice were kindly provided from K. Sekikawa (National Institute of Agrobiological Sciences, Tsukuba, Japan). These mice were backcrossed to the BALB/c strain mice for 8 generations. BALB/c mice, BALB/c-nu/nu mice, and BALB/cscid/scid mice were purchased from Clea. B10.D2/n (C57BL/6 congenic) mice were purchased from Japan SLC Inc. BALB.B (BALB/c congenic) mice were provided by $\mathrm{T}$. Shiroishi (National Institute of Genetics, Mishima, Japan). Age- and gender-matched mice were used in each experiment. Mice were kept under specific pathogen-free conditions in an environmentally controlled clean room at the Center for Experimental Medicine, Institute of Medical Science, University of Tokyo, Japan. The animal experiments were approved by the Committee for Animal Experiments of the Institute of Medical Science, University of Tokyo. Gene manipulation experiments were carried out according to the law for such experiments.

Thymocyte, splenocyte, and $T$ cell preparation and transfer. Donor mice for splenocyte or arthritic T cell transfer were between 8 and 12 weeks old, and those for nonarthritic $\mathrm{T}$ cell transfer were between 4 and 5 weeks old. Cells were prepared from spleen, thymus, and LNs (axillary, inguinal, branchial, 
cervical, and popliteal) as described previously (15). For T cell purification, spleen and LN cells were washed and passed through a nylon wool column, treated with anti-mouse B220 and Mac-1 magnetic beads and passed through a MACS column (Miltenyi Biotec). Purified $\mathrm{CD}^{+} \mathrm{T}$ cells were less than $92 \% \mathrm{CD3}^{+}$. Prepared cells were resuspended in $0.2 \mathrm{ml}$ PBS and i.v. transferred into BALB/c-nu/nu mice. Numbers of transferred cells per mouse were $10^{8}$ cells for thymocyte transfers, $4 \times 10^{7}$ cells for total splenocyte transfers, and $2 \times 10^{7}$ cells for T cell-depleted splenocyte and T cell transfers.

Incidence of arthritis and the severity score were judged macroscopically and histologically as described previously (9). Briefly, the severity score was judged by eye: grade $0=$ normal, grade 1 = light swelling of the joint and/or redness of the footpad, grade 2 = obvious swelling of the joint, and grade 3 = severe swelling and fixation of the joint. The severity score was calculated for all 4 limbs, giving a maximal score of 12 points for one mouse.

$B M$ cell preparation and transfer. Donor mice were between 4 and 8 weeks old. BM cells from femurs, tibiae, and pelves were treated with a hemolysis buffer (17 mM Tris- $\mathrm{HCl}$ and $\left.140 \mathrm{mM} \mathrm{NH}_{4} \mathrm{Cl}, \mathrm{pH} 7.2\right)$ to remove red blood cells. $\mathrm{T}$ cells were removed by treating with anti-mouse Thy 1.2 magnetic beads and then passed through a MACS column. T cell-depleted and purified BM cells $\left(10^{7}\right.$ cells $)$ in $0.2 \mathrm{ml}$ PBS were i.v. transferred into lethally irradiated $(750 \mathrm{rad})$ recipient mice.

$T$ cell activation, cytokine ELISA, and RT-PCR. CD4 ${ }^{+} \mathrm{T}$ cells were purified as described (15). Purified T cells $\left(2 \times 10^{5}\right.$ cells) were plated on a 96 -well plate coated with 1 or $10 \mu \mathrm{g} / \mathrm{ml}$ of anti-mouse CD3 mAb (145-2C11; BD Biosciences - Pharmingen) in a final volume of $200 \mu \mathrm{l}$ RPMI 1640 plus $10 \%$ FCS and cultured for 48 hours. Culture supernatant was then collected and cell proliferation was measured by incorporation of $\left[{ }^{3} \mathrm{H}\right]$ thymidine (Amersham Biosciences) (15). IFN- $\gamma$, IL-4, and TNF- $\alpha$ levels in culture were measured by ELISA as described previously $(22,29)$. For the IL-1Ra ELISA, polyclonal goat anti-mouse IL-1Ra $(1 \mu \mathrm{g} / \mathrm{ml}, \mathrm{R} \& \mathrm{D}$ Systems Inc.) and polyclonal biotinylated goat anti-mouse IL-1Ra $(2 \mu \mathrm{g} / \mathrm{ml}$, R\&D Systems Inc.) Abs were used as capture and detection Abs, respectively. StreptavidinAP (SouthernBiotech) and substrate (Sigma-Aldrich) were used for detection. Recombinant mouse IL-1Ra (R\&D Systems Inc.) was used as a standard. The detection limit was $3.9 \mathrm{pg} / \mathrm{ml}$.

Total RNAs were isolated from BALB/c T cells or $\mathrm{T}$ cell-depleted splenocytes using Trizol reagent (Invitrogen Corp.). RNAs were denatured in the presence of oligo (dT)12-18 primer and then reverse transcribed using SuperScript (Invitrogen) at $42^{\circ} \mathrm{C}$ for 1 hour. PCR was performed for 30 cycles that was within log-phase amplification stages for the PCR products. The primer sequences were as follows: IL-1Ra forward primer, $5^{\prime}$ GACCCTGCAAGATGCAAGCC-3'; IL-1Ra reverse primer, 5'-GAGCGGATGAAGGTAAAGCG-3'; $\beta_{2} \mathrm{~m}$ forward primer, $5^{\prime}$-TGACCGGCTTGTATGCTATC-3'; $\beta_{2}$ m reverse primer, $5^{\prime}$-CAGTGTGAGCCAGGATATAG-3'. These IL-1Ra primers detect both secreted and intracellular forms of IL-1Ra.

Intracellular staining of cytokines. For the intracellular staining for IL-1Ra, PECs, or $\mathrm{CD}^{+}$, T cells were prepared from BALB/c or IL-1 $\mathrm{Ra}^{-/-}$ mice. PECs were stimulated with LPS $(5 \mu \mathrm{g} / \mathrm{ml})$ for 3 hours, followed by LPS stimulation with $2 \mu \mathrm{M}$ monensin for 12 hours, then cells were suspended in a staining buffer (PBS containing $2 \%$ FCS and $0.01 \%$ sodium azide). After blocking with anti-Fc $\gamma \mathrm{RII} / \mathrm{III}$ receptor $\mathrm{mAb}$ (BD Biosciences - Pharmingen), cells were treated with FITC-anti-CD11b mAb (BD Biosciences - Pharmingen). Splenocytes were stimulated with soluble anti-CD3 $\mathrm{mAb}(1 \mu \mathrm{g} / \mathrm{ml})$, and purified $\mathrm{CD}^{+} \mathrm{T}$ cells were stimulated with plate-coated anti-CD3 $\mathrm{mAb}(1 \mu \mathrm{g} / \mathrm{ml})$ for 72 hours, and the GolgiPlug (BD Biosciences - Pharmingen) was added for the final 6 hours of stimulation. Cells were treated with anti-FcyRII/III receptor $\mathrm{mAb}$ and stained with cychrome-anti-CD4 mAb (BD Biosciences - Pharmingen). These cells were then fixed with PBS containing $4 \%$ paraformaldehyde for 20 minutes. After washing with a permeabilization buffer (PBS con- taining $10 \mathrm{mM}$ HEPES, $0.1 \%$ BSA, and $0.5 \%$ Triton X-100), cells were incubated with goat anti-mouse IL-1Ra $\mathrm{Ab}$ ( $\mathrm{R} \& \mathrm{D}$ Systems Inc.) or isotype-matched control Ab (goat IgG; R\&D Systems Inc.) in the permeabilization buffer for 30 minutes at $4{ }^{\circ} \mathrm{C}$. Cells were then washed with the permeabilization buffer and stained with Cy5-donkey-anti-goat IgG (Jackson ImmunoResearch Laboratories).

For intracellular cytokine staining for IFN- $\gamma$, IL- 4 , and TNF- $\alpha$, synovial tissues were dissected from the ankle joints of IL-1 $\mathrm{Ra}^{-/-}$mice who had already developed arthritis and normal ankle joints of WT mice. These joints were digested in a cocktail of $2.4 \mathrm{mg} / \mathrm{ml}$ hyaluronidase (Sigma-Aldrich), $1 \mathrm{mg} /$ $\mathrm{ml}$ collagenase (Wako Pure Chemical Industries) and $100 \mu \mathrm{g} / \mathrm{ml}$ DNase I (Sigma-Aldrich) in RPMI plus $10 \% \mathrm{FBS}$ for 1.5 hours at $37^{\circ} \mathrm{C}$. The cells were filtered through a nylon mesh, washed with RPMI plus $10 \% \mathrm{FBS}$, then stimulated with PMA (10 ng/ml) and Ionomycin (400 ng/ml; Sigma-Aldrich) for 6 hours at $37^{\circ} \mathrm{C}$ with $2 \mu \mathrm{M}$ monensin. These cells were blocked with anti$\mathrm{F} \gamma \gamma \mathrm{RII} / \mathrm{III}$ receptor $\mathrm{mAb}$ and stained with cell lineage-specific Abs against cell surface molecules, then fixed in $4 \%$ paraformaldehyde for 20 minutes, resuspended in the permeabilization buffer, and stained with anti-cytokine Abs for 45 minutes at $4^{\circ} \mathrm{C}$. Abs used for the cell lineage-specific staining were as follows: FITC-anti-CD11b, allophycocyanin-anti-TCR- $\beta$, CyChrome-anti$\mathrm{CD} 4$, and allophycocyanin-anti-CD8 (BD Biosciences - Pharmingen). Those used for intracellular staining were as follows: PE-anti-IFN- $\gamma$, PE-anti-IL-4 (BD Biosciences - Pharmingen), and PE-anti-TNF- $\alpha$ (eBioscience). Cells were washed with the permeabilization buffer and analyzed using FACSCalibur by CellQuest software (BD).

Flow cytometric analysis of costimulatory molecules. CD40L and OX40 expression on $\mathrm{CD}^{+} \mathrm{T}$ cells was analyzed as described previously (15). Briefly, for CD40L expression, purified CD4 ${ }^{+} \mathrm{T}$ cells on 12 -well plates $\left(1 \times 10^{6}\right.$ cells/well $)$ were stimulated with plate-coated anti-CD3 mAb with or without mouse recombinant TNF- $\alpha$ (Peprotech) in the presence of $1 \mu \mathrm{g}$ of biotinylated anti-mouse CD40L mAb (MR-1; BD Biosciences - Pharmingen) or biotinylated hamster IgG (eBioscience) as an isotypematched control $\mathrm{Ab}$ for 24 hours. For OX 40 expression, $\mathrm{CD} 4^{+} \mathrm{T}$ cells were stimulated with plate-coated anti-CD3 mAb with or without TNF- $\alpha$ for 72 hours. Cells were stained with allophycocyanin-anti-mouse-CD4 mAb (PharMingen) and either biotinylated anti-mouse OX40 mAb (OX86, eBioscience) or biotinylated rat IgG (eBioscience), followed by staining with PE-streptavidin (BD Biosciences - Pharmingen).

Antibody preparation and treatment. Anti-OX40L Ab and anti-CD40L Ab were produced in hybridoma cell lines, MGP34 and MR-1, respectively. For OX40L Ab preparation, hybridoma cells were allowed to proliferate in ascites of $n u / n u$ mice for 7-10 days or cultured in serum-free medium with the iMAb Monoclonal Antibody Production Kit (Diagnostic Chemicals Ltd.) for 4 weeks. Ascites and culture supernatant was collected and Abs were purified using Protein A column (Amersham Biosciences). For CD40L $\mathrm{Ab}$ preparation, hybridoma cells were cultured in serum-free medium for 4 weeks. Supernatant was collected and Abs were purified using Protein G column (Amersham Biosciences). Anti-OX40L Ab $(500 \mu \mathrm{g})$ or anti-CD40L $\mathrm{Ab}(250 \mu \mathrm{g})$ was intraperitoneally injected into nonarthritic IL-1 $\mathrm{Ra}^{-/-}$mice twice a week for 6 weeks. Rat IgG or hamster IgG (Cappel, ICN Pharmaceuticals) was injected as the isotype control for anti-OX40L or anti-CD40L $\mathrm{Ab}$, respectively. Mice treated with Abs were between 4 and 6 weeks old. Arthritic score was inspected at the time of Ab injection.

Statistics. The repeated-measures ANOVA-Fisher's protected least significant different test (post hoc test) or the chi-square test for independence was used for statistical evaluation of incidence. The 2-way ANOVA was used for statistical evaluation of the arthritic score. The statistical significance of affected mice scores was calculated from the point at which 2 or more mice of each genotype became arthritic. The Student's $t$ test was used for statistical evaluation of the results except for incidence and score. 


\section{Acknowledgments}

We thank K. Sekikawa for TNF- $\alpha^{-/-}$mice, T. Shiroishi for BALB.B mice, S. Mori and T. Nakajima (University of Tokyo, Tokyo, Japan) for histological sections, and S.J. Galli (Stanford University School of Medicine, Stanford, California, USA) for support in the experiments. We also thank all the members of the lab for their discussion and help in animal care. This work was supported by grants from the Ministry of Education, Culture, Sport, and Science of Japan; the Ministry of Health and Welfare of Japan; CREST; the Japan Society for the Promotion of Science; and the Japan Rheumatism Foundation.

Received for publication December 5, 2003, and accepted in revised form October 5, 2004.

1. Feldmann, M., Brennan, F.M., and Maini, R.N. 1996. Role of cytokines in rheumatoid arthritis. Annu. Rev. Immunol. 14:397-440.

2. Firestein, G.S., and Zvaifler, N.J. 1992. Rheumatoid arthritis: a disease of disordered immunity. In Inflammation: basic principles and clinical correlates. 2nd edition. J.I. Gallin, I.M. Goldstein, and R. Snyderman, editors. Raven Press, Ltd. New York, New York, USA. 959-975.

3. Feldmann, M., and Maini, R.N. 2001. Anti-TNF- $\alpha$ therapy of rheumatoid arthritis: what have we learned? Annu. Rev. Immunol. 19:163-196.

4. Tocci, M.J., and Schmidt, J.A. 1997. Interleukin-1: Structure and function. In Cytokines in health and disease. 2nd edition. D.G. Remick and J.S. Friedland, editors. Marcel Dekker, Inc. New York, New York, USA. $1-27$

5. Iwakura, Y. 2002. Roles of IL-1 in the development of rheumatoid arthritis: consideration from mouse models. Cytokine Growth Factor Rev. 13:341-355.

6. Arend, W.P., Malyak, M., Guthridge, C.J., and Gabay, C. 1998. Interleukin-1 receptor antagonist: role in biology. Annu. Rev. Immunol. 16:27-55.

7. Kollias, G., Douni, E., Kassiotis, G., and Kontoyiannis, D. 1999. On the role of tumor necrosis factor and receptors in models of multiorgan failure, rheumatoid arthritis, multiple sclerosis and inflammatory bowel disease. Immunol. Rev. 169:175-194.

8. Kontoyiannis, D., Pasparakis, M., Pizarro, T.T., Cominelli, F., and Kollias, G. 1999. Impaired on/ off regulation of TNF biosynthesis in mice lacking TNF AU-rich elements: implications for joint and gut-associated immunopathologies. Immunity. 10:387-398.

9. Horai, R., et al. 2000. Development of chronic inflammatory arthropathy resembling rheumatoid arthritis in interleukin 1 receptor antagonist-deficient mice. J. Exp. Med. 191:313-320.

10. Niki, Y., et al. 2001. Macrophage- and neutrophildominant arthritis in human IL- $1 \alpha$ transgenic
Address correspondence to: Yoichiro Iwakura, Center for Experimental Medicine, Institute of Medical Science, University of Tokyo, Shirokanedai, Minato-ku, Tokyo 108-8639, Japan. Phone: 81-3-54495536, Fax: 81-3-5449-5430; E-mail: iwakura@ims.u-tokyo.ac.jp.

Susumu Nakae's present address is: Department of Pathology, Stanford University School of Medicine, Stanford, California, USA.

Taizo Matsuki's present address is: Japan Science and Technology Agency, Tokyo, Japan.

Katsuko Sudo's present address is: Animal Research Center, Tokyo Medical University, Tokyo, Japan. mice. J. Clin. Invest. 107:1127-1135.

11. Mima, T., et al. 1995. Transfer of rheumatoid arthritis into severe combined immunodeficient mice. The pathogenetic implications of $\mathrm{T}$ cell populations oligoclonally expanding in the rheumatoid joints. J. Clin. Invest. 96:1746-1758.

12. Weinberg, A.D. 1998. Antibodies to OX-40 (CD134) can identify and eliminate autoreactive T cells: implications for human autoimmune disease. Mol. Med. Today. 4:76-83.

13. van Kooten, C., and Banchereau, J. 2000. CD40CD40 ligand. J. Leukoc. Biol. 67:2-17.

14. Weinberg, A.D. 2002. OX40: targeted immunotherapy - implications for tempering autoimmunity and enhancing vaccines. Trends Immunol. 23:102-109.

15. Nakae, S., Asano, M., Horai, R., Sakaguchi, N., and Iwakura, Y. 2001. IL-1 enhances T cell-dependent antibody production through induction of CD40 ligand and OX40 on T cells. J. Immunol. 167:90-97.

16. Kitagawa, H., et al. 1993. Analyses of origin of synovial cells and repairing mechanisms of arthritis by allogeneic bone marrow transplantation. Immunobiology. 188:99-112.

17. Nakae, S., et al. 2003. IL-17 production from activated T cells is required for the spontaneous development of destructive arthritis in mice deficient in IL-1 receptor antagonist. Proc. Natl. Acad. Sci. U. S. A. 100:5986-5990.

18. Thorbecke, G.J., et al. 1992. Involvement of endogenous tumor necrosis factor $\alpha$ and transforming growth factor $\beta$ during induction of collagen type II arthritis in mice. Proc. Natl. Acad. Sci. U. S. A. 89:7375-7379.

19. Joosten, L.A., et al. 1999. IL- $1 \alpha \beta$ blockade prevents cartilage and bone destruction in murine type II collagen-induced arthritis, whereas TNF$\alpha$ blockade only ameliorates joint inflammation. J. Immunol. 163:5049-5055.

20. Ji, H., et al. 2002. Critical roles for interleukin 1 and tumor necrosis factor $\alpha$ in antibody-induced arthritis. J. Exp. Med. 196:77-85.

21. Lubberts, E., et al. 2001. IL-1-independent role of IL-17 in synovial inflammation and joint destruction during collagen-induced arthritis. J. Immunol. 167:1004-1013.

22. Nakae, S., et al. 2002. Antigen-specific T cell sensitization is impaired in IL-17-deficient mice, causing suppression of allergic cellular and humoral responses. Immunity. 17:375-387.

23. Nakae, S., Nambu, A., Sudo, K., and Iwakura, Y. 2003. Suppression of immune induction of collagen-induced arthritis in IL-17-deficient mice. J. Immunol. 171:6173-6177.

24. Infante-Duarte, C., Horton, H.F., Byrne, M.C., and Kamradt, T. 2000. Microbial lipopeptides induce the production of IL-17 in Th cells. J. Immunol. 165:6107-6115.

25. Chabaud, M., and Miossec, P. 2001. The combination of tumor necrosis factor alpha blockade with interleukin-1 and interleukin-17 blockade is more effective for controlling synovial inflammation and bone resorption in an ex vivo model. Arthritis Rheum. 44:1293-1303.

26. Mauri, C., Mars, L.T., and Londei, M. 2000. Therapeutic activity of agonistic monoclonal antibodies against CD40 in a chronic autoimmune inflammatory process. Nat. Med. 6:673-679.

27. Webster, E.A., et al. 1999. An aggressive form of polyarticular arthritis in a man with CD154 mutation (X-linked hyper-IgM syndrome). Arthritis Rheum. 42:1291-1296.

28. Horai, R., et al. 1998. Production of mice deficient in genes for interleukin (IL)- $1 \alpha$, IL- $1 \beta$, IL- $1 \alpha / \beta$, and IL- 1 receptor antagonist shows that IL-1 $\beta$ is crucial in turpentine-induced fever development and glucocorticoid secretion. J. Exp. Med. 187:1463-1475.

29. Nakae, S., Asano, M., Horai, R., and Iwakura, Y. 2001. Interleukin- $1 \beta$, but not interleukin- $1 \alpha$, is required for T-cell-dependent antibody production. Immunology. 104:402-409. 